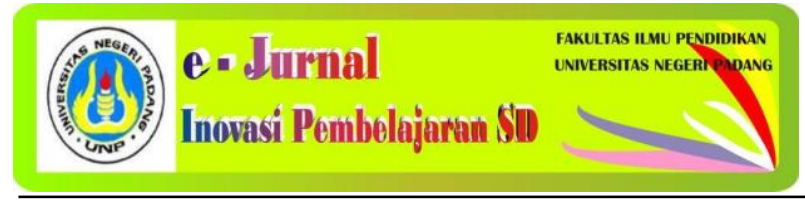

Volume 6, Nomor 2, 2018

Available on: http://ejournal.unp.ac.id/students/index.php/pgsd

\title{
Peningkatan Hasil Belajar Siswa Menggunakan Model Talking Stick di Kelas V Sekolah Dasar
}

\author{
Muhammad Ridwan ${ }^{1)}$, Desyandri $^{2)}$, Yanti fitria ${ }^{3)}$ \\ ${ }^{1)}$ Mahasiswa, Universitas Negeri Padang, Indonesia \\ ${ }^{2}$ Pembimbing 1, Universitas Negeri Padang, Indonesia \\ ${ }^{3}$ Pembimbing 2, Universitas Negeri Padang, Indonesia
}

Email: ${ }^{1)}$ Ridwanmuhammad09@gmail.com, ${ }^{2)}$ desyandri@fip.ac.id, ${ }^{3)}$ yanti fitria@ fip.unp.ac.id

\begin{abstract}
Abstrak
Penelitian ini bertujuan mendeskripsikan peningkatan hasil belajar siswa dalam pembelajaran IPS menggunakan model pembelajaranTalking Stick di kelas V SD. Jenis penelitian yang digunakan ialah Penelitian Tindakan Kelas dengan menggunakan pendekatan kualitatif dan kuantitatif.Subjek dalam penelitian ini ialah guru dan siswa kelas V SD yang berjumlah 20 orang.Penelitian dilaksanakan dalam dua siklus dengan prosedur perencanaan, pelaksanaan, pengamatan, dan refleksi.Hasil penelitian menunjukkan pembelajaran IPS menggunakan model pembelajaranTalking Stick dapat meningkatkan hasil belajar siswa di SD Negeri 07 Sentosa Padang Gelugur Kabupaten Pasaman.
\end{abstract}

Kata Kunci: Hasil Belajar, Pembelajaran IPS, Talking stick

\begin{abstract}
This study aims to describe the improvement of student learning outcomes in learning IPS using Talking Stick learnig model in the fifth grade of elementary school. The type of research used is Class Action Research using qualitative and quantitative approaches. Subjects in this study were teachers and fourth grade elementary school students totaling 20 people. The research was carried out in two cycles with planning, implementation, observation and reflection procedures. The results showed that the learning of IPS using Talking Stick learnig model can improve student learning outcomes in SD Negeri 07 Sentosa Padang Gelugur Pasaman District.
\end{abstract}

Keywords: Learning Outcomes, Social Studies Learning, Talking Stick 


\section{PENDAHULUAN}

Ilmu Pengetahuan Sosial (IPS) merupakan salah satu mata pelajran yang diberikan mulai dari SD/MI/SDLB sampai ke perguruan tinggi. Depdiknas (2006:575) menyatakan "IPS merupakan salah satu mata pelajaan yang diberikan dari tingkat sekolah dasar hingga tingkat menengah yang mengkaji seperangkat fakta, konsep, dan generalisasi yang berkaitan dengan isu sosial". Banks dalam Sapriya dkk (2007:4) menyatakan bahwa" IPS di sekolah di sekolah penekanannya pada aspek pengembangan berpikir siswa sebagai bagian dari masyarakat dan berperan serta dalam memecahkan masalah".

Peran penting pendidikan menumbuhkembangkan kesadaran untuk tetap menjaga keharmonisan baik dalam kehidupan individu, sosial, masyarakat, dan bangsa (Desyandri, 2014). Pembelajaran IPS tidak hanya bersifat hafalan dan pemahaman konsep saja, tetapi bagaimana proses dalam pembelajaran itu lebih bermakna, membuat siswa lebih aktif, mengembangkan rasa ingin tahu, dan mengembangkan kemampuan siswa dalam ranah kognitif, afektif, dan psikomotor. Proses pembelajaran tidak terlepas dari ketiganya saling terkait satu sama lain, pengetahuan yang membentuk keterampilan dan pengetahuan yang membentuk sikap logis, kritis, cermat, kreatif, dan disiplin. Di samping itu, pembelajaran yang dilakukan guru secara

keseluruhan belum maksimal dan masih menggunakan pembelajaran konvensional yang didominasi oleh ceramah (Desyandri, 2012).

Kenyataan yang peneliti temukan saat melakukan observasi dan tanya jawab dengan guru kelas V SD Negeri 07 Sentosa ditemukan beberapa permasalahan diantaranya :1) Pelaksanaan pembelajaran yang tidak sesuai dengan RPP, 2) Minimnya guru mengembangkan model pembelajaran, 3) Pembelajaran masih bersifat konvensional, menurut Sanjaya (2006:259) "bahwa pada pembelajaran konvensional siswa ditempatkan sebagai obyek belajar yang berperan sebagai penerima informasi secara pasif ",sehingga kurang menarik perhatian dan motivasi siswa dalam belajar, 4) Ketika proses pembelajaran guru kurang mengoptimalkan pemahaman siswa terhadap materi pembelajaran,sehingga dapat mempengaruhi hasil belajar siswa, 5) Dalam pembelajaran IPS tersebut guru juga kurang mengaktifkan siswa dalam kegiatan kelompok maupun diri sendiri, sehingga siswa monoton,kurang dan jarang mengelurakan pendapat dalam proses pembelajaran.

Sebagai akibat dari kondisi yang dikemukakan di atas berdampak pada siswa, permasalahan dari aspek siswa yaitu, (1) Siswa kurang aktif dalam belajar karena terbiasa menerima penyampaian materi oleh guru. (2) 
Siswa sulit dalam menghafal materi karena terlalu banyak (3)Siswa kurang berani berbicara untuk mengemukakan pendapat. (4) Siswa hanya duduk, mencatat dan mendengarkan penyampain materi oleh guru tanpa memahami betul materi pembelajaran. (5) Rendahnya hasil belajar siswa dalam pembelajaran IPS.

Dilihat rata-rata nilai semester II siswa kelas IV SD Negeri 07 Sentosa Padang Gelugur pada mata pelajaran IPS belum memenuhi Kriteria Ketuntasan Minimal (KKM) yang sudah ditetapkan, yaitu 75. Dari 20 siswa, hanya sebanyak 5 atau $25 \%$ siswa yang mencapai KKM. Sedangkan 15 siswa atau 75\% nilainya di bawah KKM. Hal ini juga terlihat pada rata-rata kelas keseluruhan yaitu hanya 62,2.

Banyak model pembelajaran yang dapat dipilih oleh seorang guru dalam menyampaikan materi pelajaran untuk meningkatkan aktivitas peseta didik dalam proses pembelajaran, salah satunya adalah Talking Stick karena menurut Isjoni (2010:21) "Model pembelajaran Talking Stick adalah model pembelajaran yang bertujuan untuk menghargai pendapat dan memberikan kesempatan kepada orang lain untuk mengemukakan gagasannya dengan menyampaikan pendapat mereka secara kelompok."

Selain itu Talking Stick juga member motivasi pada siswa untuk aktif dalam belajar dan bertanya seperti yang dijelaskan Istarani (2012:89) “Talking Stick merupakan model pembelajaran yang mendorong peserta didik untuk berani mengemukakan pendapatnya sehingga siswa lebih aktif dan mengerti dalam pembelajaran,hal ini tentu akan diharapkan untuk dapat meningkatkan hasil belajar siswa".

Berdasarkan permasalah yang telah diuraikan di atas, maka secara umum rumusan masalah secara umum dalam penelitian ini adalah "Bagaimanakah penggunaan model Talking Stick untuk meningkatkan hasil belajar IPS di kelas V SD Negeri 07 Sentosa Padang Gelugur Kabupaten Pasaman”. Sedangkan rumusan masalah secara khusus adalah mendeskripsikan bagaimana rencana pelaksanaan pembelajaran, pelaksanaan pembelajaran, dan hasil belajar siswa dalam pembelajaran IPS.

Sesuai dengan rumusan masalah di atas, maka tujuan dari penelitian ini secara umum adalah untuk mendeskripsikan peningkatan hasil belajar siswa dalam pembelajaran IPS menggunakan model Talking Stick di kelas V SD Negeri 07 Sentosa Padang Gelugur Kabupaten Pasaman. Sedangkan tujuan penelitian ini secara khusus adalah mendeskripsikan rencana pelaksanaan pembelajaran, pelaksanaan pembelajaran, dan peningkatan hasil belajar belajar siswa dalam pembelajaran IPS.

\section{METODE PENELITIAN}

Penelitian ini adalah penelitian tindakan kelas yang dilaksanakan di kelas V SD Negeri 07 Sentosa Padang Gelugur Kabupaten Pasaman 
dengan jumlah siswa 20 orang, 12 orang

perempuan dan 8 orang siswa laki-laki.

Penelitian ini dilakukan secara kolaboratif antara peneliti dengan guru kelas V SD Negeri 07Sentosa Padang Gelugur.

Penelitian dilakukan pada semester 1 tahun ajaran 2018/2019 dengan jumlah 2 siklus.Siklus I terdiri dari 2 kali pertemuan, dan siklus II terduru dari 1 kali pertemuan.

Penelitian ini dimulai dengan menyusun rencana pelaksanaan pembelajaran (RPP), menerapkan RPP yang sudah disusun, pengamatan yang dilakukan oleh observer dan refleksi terhadap tindakan yang sudah dilakukan. Hal ini sesuai dengan yang dijelaskn oleh Kemmis (dalam Kunandar,2008:43), "Proses penelitian tindakan merupakan proses daur ulang atau siklus yang dimulai dari aspek mengembangkan perencanaan,melakukan tindakan sesuai rencana, melakukan observasi terhadap tindakan,dan melakukan refleksi perenungan terhadap perencanaan, kegiatan pembelajaran, dan kesuksesan hasil yang diperoleh."Sesuai dengan prinsip umum penelitian tindakan setiap tahapan dan siklusnya selalu partisipatoris dan kolaboratif antara peneliti dan praktisi (guru dan kepala sekolah) dalam sistem persekolahan.

Data dakam penelitian ini dikumpulkan dengan observasi, tes, dan nontes. Siswa yang dianggap tuntas apabila telah mencapai Kriteria Ketuntasan Minimum yang telah ditetapkan sekolah yaitu 75 atau $75 \%$.

\section{HASIL PENELITIAN}

\section{Siklus I}

Siklus I dilaksanakan sebanyak dua kali pertemuan pada tanggal 17 dan 20 Juli 2018.Penelitian dilakukan dengan empat tahapan yaitu perencanaan, pelaksanaan, pengamatan, dan refleksi.

\section{Perencanaan}

Perencanaan dibuat berdasarkan langkah model pembelajaranTalking Stick.Rencana pelaksanaan pembelajaran ini disusun oleh peneliti berkolaborasi dengan observer yaitu guru kelas V SD Negeri 07 Sentosa Padang Gelugur Kabupaten Pasaman.Rencana pelaksanaan pembelajaran yang akan dilaksanakan memuat identitas sekolah, mata pelajaran, alokasi waktu, standar kompetensi, kompetensi dasar, indikator, tujuan pembelajaran, materi pembelajran, metode pembelajaran, model pembelajaran, media dan sumber belajar, kegiatan pembelajaran, dan penilaian. Materi pembelajaran yang dibahas pada siklus I pertemuan 1 adalah masuknya agama Hindu ke Indonesia sedangkan untuk materi pembelajaran yang dibahas pada siklus I pertemuan 2 adalah masuknya agama Budha ke Indonesia.

\section{Pelaksanaan}

Pelaksanaan pembelajaran IPS menggunakan model pembelajaranTalking StickSD Negeri 07 Sentosa padang Gelugur Kabupaten Pasaman dilaksanakan sesuai 
perencanaan yang telah dirancang sebelumnya.

Siswa yang hadir pada pertemuan ini sebanyak 20 orang.Dalam pelaksanaan tindakan, peneliti dibantu oleh guru kelas V sebagai observer.

Pelaksanaan tindakan dibagi menjadi tiga tahap yaitu kegiatan awal, kegiatan ini, dan kegiatan akhir, sesuai dengan tahap yang telah disusun dalam RPP.

\section{Pengamatan}

Pengamatan dilakukan terhadap Rencana Pelaksanaan Pembelajaran (RPP), pelaksanaan aspek guru dan aspek siswa dan hasil belajar. Pengamatan penilaian pada Rencana Pelaksanaan Pembelajaran (RPP) pada siklus I adalah dengan rata-rata $87,45 \%$ sedangkan untuk aspek guru adalah dengan rata-rata 85,3\% dan untuk aspek siswa dengan rata-rata $82,25 \%$. Untuk hasil belajar siswa siklus I mendapatkan rata-rata 74,2 .

\section{Refleksi}

Berdasarkan hasil observasi dan tes yang telah dilakukan maka dapat didapatkan bahwa hasil belajar siswa belum maksimal.Dengan demikian, peningkatan hasil belajar siswa dalam pembelajaran IPS akan peneliti lanjutkan pada siklus II dengan lebih baik sesuai dengan rancangan rencana pelaksanaan pembelajaran dengan menggunakan model pembelajaran Talking Stick.

\section{Siklus II}

Siklus II dilaksanakan sebanyak satu kali pertemuan pada tanggal 23 juli 2018. Penelitian dilakukan dengan empat tahapan yaitu perencanaan, pelaksanaan, pengamatan, dan refleksi.

\section{Perencanaan}

Perencanaan dibuat berdasarkan langkah model pembelajaran Talking Stick .Rencana pelaksanaan pembelajaran ini disusun oleh peneliti berkolaborasi dengan observer yaitu guru kelas V SD Negeri 07 Sentosa Padang Gelugur Kabupaten Pasaman.Rencana pelaksanaan pembelajaran yang akan dilaksanakan memuat identitas sekolah, mata pelajaran, alokasi waktu, standar kompetensi, kompetensi dasar, indikator, tujuan pembelajaran, materi pembelajran, metode pembelajaran, model pembelajaran, media dan sumber belajar, kegiatan pembelajaran, dan penilaian. Materi pembelajaran yang dibahas pada siklus II adalah permasalahan sosial kemiskinan.

\section{Pelaksanaan}

Pelaksanaan pembelajaran IPS menggunakan model pembelajaranTalking StickSD Negeri 07 Sentosa Padang Gelugur Kabupaten Pasaman dilaksanakan sesuai perencanaan yang telah dirancang sebelumnya. Siswa yang hadir pada pertemuan ini sebanyak 20 orang.Dalam pelaksanaan tindakan, peneliti dibantu oleh guru kelas V sebagai observer.

Pelaksanaan tindakan dibagi menjadi tiga tahap yaitu kegiatan awal, kegiatan ini, dan kegiatan akhir, sesuai dengan tahap yang telah disusun dalam RPP.

\section{Pengamatan}




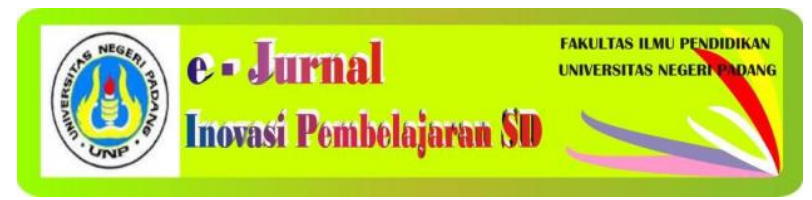

Pengamatan dilakukan terhadap Rencana Pelaksanaan Pembelajaran (RPP), pelaksanaan aspek guru dan aspek siswa dan hasil belajar. Pengamatan penilaian pada Rencana Pelaksanaan Pembelajaran (RPP) pada siklus II adalah dengan rata-rata $95,8 \%$ sedangkan untuk aspek guru adalah dengan rata-rata 95,8\% dan untuk aspek siswa dengan rata-rata 93,75\%. Untuk hasil belajar siswa siklus II mendapatkan rata-rata 83,1 .

\section{Refleksi}

Berdasarkan hasil observasi dan tes yang telah dilakukan maka dapat disimpulkan bahwa hasil belajar siswa sudah mencapai kriteria keberhasilan yang diinginkan dan kriteria ketuntasan minimum yang telah ditetapkan.Dengan demikian, peningkatan hasil belajar siswa dalam pembelajaran IPS dengan menggunakan model pembelajarantalking Stick di kelas V SD Negeri 02 Pauh Sangik sudah berhasil.

\section{PEMBAHASAN}

\section{Siklus I}

\section{Perencanaan}

Hasil penelitian pelaksanaan model pembelajaran Talking Stick dalam pembelajaran masuknya agama Hindu ke Indonesia pada mata pelajaran IPS di kelas V SD Negeri 07 Sentosa Padang Gelugur Kabupaten Pasaman, mengungkapkan perencanaan yang dimulai dengan membuat rancangan dalam bentuk
Volume 6, Nomor 2, 2018

Available on: http://ejournal.unp.ac.id/students/index.php/pgsd

Rencana Pelaksanaan Pembelajaran (RPP) belum dapat dikatakan baik.

Pada aspek pemilihan materi ajar, yang mana materi ajar yang dipilih tidak sesuai dengan karakteri siswa, hal ini mengakibatkan siswa susah memahami materi yang diajarkan. Pengorganisasian materi ajar juga tidak sesuai dengan alokasi waktu yang tersedia, yang mana materi terlalu banyak sedangkan waktu yang tersedia tidak mencukupi.Hal ini menyebabkan materi tidak tersampaikan secara sempurna pada siswa. Hendaknya sebuah perencanaan dapat menggambarkan manajemen pembelajaran yang akan dilaksanakan agar kompetensi yang diharapkan tercapai. Sejalan dengan Depdiknas (2007:162) mengatakan bahwa "RPP adalah rencana yang menggambarkan prosedur dan pengorganisasian pembelajaran untuk mencapai satu kompetensi dasr yang ditetapkan dalam standar isi dan telah dijabarkan dalam silabus".

\section{Pelaksanaan}

Pelaksanaan pembelajran IPS dengan model pembelajaranTalking Stick pada siklus I secara umum sudah berlangsung dengan baik, namun masih ada kekurangan yang timbul dimana pelaksanaan tidak sesuai dengan perencanaan dibuat.

Beberapa hal yang menjadi catatan yaitu 1) Pada pengorganisasian materi ajar kurang luas, karena guru hanya berpedoman dengan materi yang ada di buku paket. Menurut Ahmad (2010:6) “ dalam menyusun langkah-langkah pembelajran guru haruslah memperhatikan 
keteraturan, kejelasn, alokasi waktu dan cakupan materi yang akan diajarkan.” 2) Pada tahap pemilihan sumber media pembelajran belum sesaui dengan lingkungan siswa, dan pada tahap menyusun langkah-langkah pembelajaran kurang jelas serta tidak sesuai dengan alokasi waktu. Media pembelajaran harusnya sesua dengan karakteristik siswa dan lingkungan siswa untuk mendukung keberhasilan proses pembelajran.

\section{Hasil Belajar Siswa}

Dalam proses belajar seorang akan mengalami perubahan. Perubahan-perubahan inilah yang disebut hasil belajar.Sudjana (2009:22) "Hasil belajar adalah kemampuankemampuan yang dimilliki siswa setelah ia menerima pengalaman belajarnya".

Pencapaian hasil belajar siswa sesudah melaksanakan pembelajaran masuknya agama Hindu dan Budha ke Indonesia pada siklus I sudah dikatakan baik dibandingkan sebelum diadakan tindakan.Adapun penilaian yang dilakuakn guru yaitu pada aspek kognitif, afektif, dan psikomotor.

Berdasarkan hasil evaluasi pembelajaran IPS terpadu menggunakan model Talking Stick pada siklus I pertemuan 1 untuk rata-rata hasil hasil belajar siswa dari ketiga aspek memperoleh skor 71,4 dengan kualifikasi cukup (C). Hasil penilaian peningkatan hasil belajar siswa pada pembelajaran IPS menggunakan model pembelajranTalking Stick yang diperoleh selama pelaksanaan siklus I pertemuan 1 belum tercapai sehingga pelaksanaan harus dilanjutkan ke siklus I pertemuan 2. Pada siklus I pertemuan 2 diperoleh rata-rata 77 dengan kualifikasi baik (B), sehingga didapat rata-rata pada siklus I 74,2 dengan kualifikasi (C).

Dari rata-rata hasil belajar diatas terlihat bahwa hasil belajar siswa pada sikluss I telah mengalami peningkatan, namun ada komponen dalam hasil belajar yang belum mencapai ketuntasan.Untuk memperbaiki kekurangan tersebut maka dilanjutkan pada siklus II.

\section{Siklus II}

\section{Perencanaan}

Pada siklus II, perencanaan pelaksanaan pembelajaran IPS dengan model pembelajaran Talking Stick telah dirancang denngan baik dimana pada kejelasan perumusan tujuan proses pembelajaran, pemilihan materi ajar, pemilihan sumber dan media pembelajaran, teknik pembelajaran, dan kelengkapan instrumen pembelajaran telah terlaksana dengan baik. Berdasarkan rekapitulasi data lembar pengamatan RPP diketahui bahwa perolehan presentase skor pada siklus II adalah 91,6\% dengan kualifikasi sangat baik (Purwanto, 2006:103)

Berdasarkan paparan data diatas, dapat disimpulkan bahwa perencanaan pembelajaran IPS dengan modelpembelajran Talking Stick di kelas V SD Negeri 07 Sentosa Padang Gelugur Kabupaten Pasaman telah terlaksana dengan baik pada siklus II. Sesuai dengan pendapat Mulyasa (2009:174) "kriteria rencana 
pembelajaran yang efektif dapat dilihat dari kemampuannya dalam membuat sesuatu yang benar, mengkreasikan alternatif-alternatif, mengoptimalkan berbagai sumber belajar, dan meningkatkan kualitas pembelajaran".

\section{Pelaksanaan}

Berdasarkan perencanaan yang telah disusun, pelaksanaan pembelajaran dilakukan sesuai dengan apa yang telah direncanakan yang disajikan dalam $1 \mathrm{x}$ pertemuan. Pelaksanaan pembelajaran pada siklus II sudah terlaksana dengan baik. Berdasarkan hasil pengamatan penelitian pada siklus II dapat dilihat hasil penilaian pada aspek guru adalah 95,8\% dan untuk hasil penilaian pada aspek siswa adalah 93,75\% dengan kualifikasi sangat baik (SB).

\section{Hasil Belajas Siswa}

Hasil belajar siswa pada siklus II mengalami peningkatan.Dilihat dari aspek kognitif diperoleh rata-rata 86.Aspek afektif 81,1 dan aspek psikomotor 83,1

Berdasarkan data diatas, terlihat bahwa hasil belajar IPS dengan materi masuknya agama Islam ke Indonesia di kelas V SD Negeri 07 Sentosa Padang Gelugur Kabupaten Pasaman mengalami peningkatan. Pada siklus II hasil belajar siswa diperoleh nilai rata-rata 83,1 dengan kualifikasi sangat baik menurut (Purwanto,2006:103). Dapat disimpulkan bahwa siklus II sudah sangat baik dan telah mencapai kriteria ketuntasan minimal 75.Untuk itu tidak perlu diadakan tindakan lanjut dan penelitian dapat diakhiri pada siklus II ini.

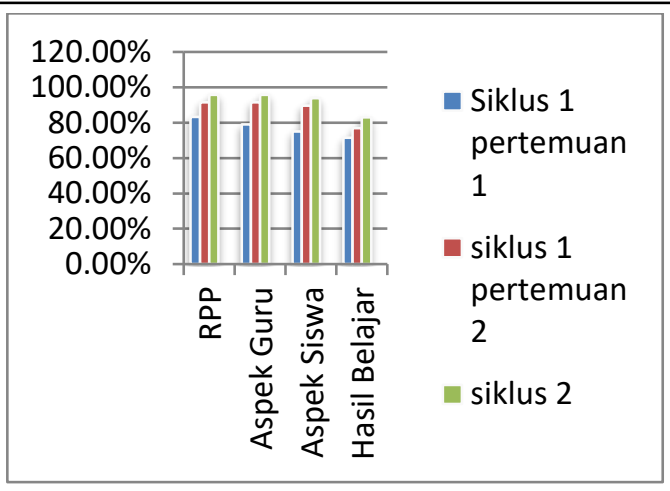

Grafik 1. Peningkatan Hasil Analisis Data Siklus I dan II

\section{SIMPULAN}

Berdasarkan hasil penelitian dan pembahasan peneliti dapat disimpulkan sebagai berikut :

\section{Perencanaan}

Pengembangan

perencanaan pembelajaran menggunakan model pembelajaran Talking Stick pada pembelajaran Ilmu Pengetahuan Sosial (IPS) dituangkan dalam bentuk RPP yang komponen penyusunannya terdiri dari Standar Kompetensi, Kompetensi Dasar, indikator, tujuan pembelajaran, materi pembelajaran, kegiatan pembelajaran, pendekatan pembelajaran, sumber dan media dan penilaian. Dalam pengembangan RPP memperhatikan 7 komponen, yaitu 1) kejelasan perumusan tujuan pembelajaran, 2) pemilihan materi ajar, 3) pengorganisasian materi ajar, 4) pemilihan sumber atau media pembelajaran, 5) langkah-langkah pembelajaran, 6) teknik pembelajaran 7) 
kelengkapan instrumen. Dari hasil analisis data, penilaian rencana pelakasanaan pembelajaran pada siklus I pertemuan 1 adalah sebesar 83,3\% dengan kualifikasi baik (B). Kemudian meningkat pada siklus I pertemuan 2 menjadi $91,6 \%$ dengan kualifikasi sangat baik (SB), dan semakin meningkat pada siklus II menjadi 95,8\% dengan kualifikasi sangat baik (SB).

\section{Pelaksanaan}

Pelaksanaan pembeajaran Ilmu Pengatahuan Ssosial (IPS) dengan menggunakan model pembelajaranTalking Stick terdiri dari tiga kegiatan pembelajaran yaitu kegiatan awal, kegiatan inti, dan kegiatan akhir. Pembelajaran IPS menggunakan model pembelajaranTalking Stick dilaksanakan dengan langkah-langkah 1) Guru menyiapkan sebuah tongkat, 2) Guru menyampaikan materi pokok yang akan dipelajari, kemudian memberikan kesempatan kepada siswa untuk membaca dan mempelajari materi pada pegangannya/ paketnya, 3) Setelah selesai membaca buku dan mempelajarinya, siswa dipersilahkan menutup bukunya ,4) Guru mengambil tongkat dan memberikan kepada siswa, setelah itu guru memberikan pertanyaan dan siswa yang memegang tongkat tersebut harus menjawabnya. Demikian seterusnya sampai sebagian besar siswa mendapat bagian untuk menjawab setiap pertanyaan dari guru, 5)
Guru memberikan kesimpulan ,6) Evaluasi ,7) Penutup.

Kegiatan pembelajaran dilaksanakan dalam dua siklus, siklus I terdiri dari dua kali pertemuan dan siklus II terdiri dari satu kali pertemuan.Penilaian pelaksanaan pembelajran menggunakan model pembelajaran Talking Stick mencakup penilaian aspek guru dan aspek siswa. Penilaian aspek guru pada siklus I pertemuan 1 mendapatkan nilai sebesar 79\% dengan kualifikasi cukup (C), kemudian meningkat pada siklus I pertemuan 2 menjadi 91,6\% dengan kualifikasi sangat baik (SB), dan semakin meningkat pada siklus II menjadi 95,8\% dengan kualifikasi sangat baik (SB).Sedangkan penilaian pelaksanaan pada aspek siswa, siklus I pertemuan 1 mendapatkan nilai sebesar 75\% dengan kualifikasi cukup (C), meningkat pada siklus I pertemuan 2 menjadi 89,5\% dengan kualifikasi baik (B), kemudian semakin meningkat pada siklus II menjadi 93,75\% dengan kualifikasi sangat baik (SB).

\section{Hasil Belajar}

Hasil belajar siswa dalam pembelajaran Ilmu Pengetahuan Sosial (IPS) dengan menggunakan model pembelajaran Talking Stick mengalami peningkatan.Hasil belajar siswa didapatkan dari penggabungan 
nilai siswa pada aspek kognitif, afektif, dan

psikomotor, yang diambil dari hasil evaluasi menggunakan lembar tes dan nontes.Pada siklus I pertemuan 1 diperoleh rata-rata hasil belajar siswa sebesar 71,4 dengan kualifikasi cukup (C), kemudian meningkat pada siklus I pertemuan 2 menjadi 77 dengan kualifikasi baik (B), dan semakin meningkat pada siklus II menjadi 83,1 dengan kualifikasi sangat baik (SB).

\section{DAFTAR RUJUKAN}

BSNP. (2006). Kurikulum Tingkat Satuan Pendidikan. Jakarta : Depdikbud

Desyandri. (2012). The Usage of Contextual Teaching and Learning (CTL) Approach to Improve Improve the Process and Learning Outcome of Singing to the Student Class III Elementary School YPKK of Universitas Negeri Padang. Jurnal Ilmiah Ilmu Pendidikan, 12(1), 36-52. Retrieved from http://pedagogi.ppj.unp.ac.id/index.php/ pedagogi/article/view/231/135

Desyandri. (2014). Peran Seni Musik dalam Pendidikan Multikultural. Jurnal Pembangunan Pendidikan; Fondasi Dan Aplikasi IP PPS UNY, 2(1), 1-11. https://doi.org/http://dx.doi.org/10.21831 /jppfa.v2i1.2613

Kunandar. (2008). Langkah Mudah Penelitian Tindakan Kelas Sebagai Pengembangan Profesi Guru. Jakarta: Rajawali Press.

Mulyasa, E. (2009). Implementasi Kurikulum Tingkat Satuan Pendidikan Kemandirian Guru dan
Kepala Sekolah. Jakarta : Bumi Aksara.

Isjoni. (2010). Cooperative learning mengembangkan kemampuan belajar berkelompok.Bandung: Alfabeta.

Istarani. (2012). 58 Model Pembelajaran Inovatif. Medan : Media Persada.

Purwanto. 2013. Evaluasi Hasil Belajar. Yogyakarta : Pustaka Belajar.

Sanjaya, W. (2011). Strategi Pembelajaran Berorientasi Standar Proses Pendidikan. Jakarta: Prenada Media Group.

Sudjana, N. (2010). Dasar-Dasar Proses Belajar Mengajar. Bandung: Sinar Baru Algensindo.

Susanto, A. (2013). Teori Belajar Pembelajaran di Sekolah Dasar. Jakarta. Prenada Media Group. 